\title{
Houses on organic farms in north-east Mazovia: Existing material and construction solutions
}

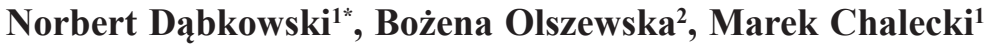 \\ ${ }^{1}$ Department of Civil and Environmental Engineering, Warsaw University of Life Sciences, Nowoursynowska 159 St, \\ 02-776 Warszawa, Poland \\ ${ }^{2}$ OMIS S.A. Kołobrzeska 8 St, 07-401 Ostrołęka, Poland, \\ "e-mail: norbert_dabkowski@sggw.pl
}

Received: 7 February 2018 / Accepted: 12 May 2018

\begin{abstract}
The study presents building materials or systems which are described in the literature and are regarded as ecological, results of the investigations on the material and construction solutions in dwelling houses of selected organic farms in north-east Mazovia and prospecting for the influence of organic farming on dwelling houses. To prepare the paper, the literature on ecological building construction and ecological farming was used, visits at farms were made (collection of documentation and conversations with owners) and statistical data on the ecological farms in the Ostrołęka and Maków counties were analysed. The investigations showed that there are no connections between the ecological farming and dwelling houses existing on these farms. The material and construction solutions applied there can be considered as non-ecological, which has been shown on the basis of the method by Dabkowski (2002b). It has been also noticed that farm owners did not benefit from the rich material heritage (i.a. related to folk architecture) of the described region when building residential houses on their farms.
\end{abstract}

Keywords: building materials, dwelling houses evaluation, ecological building construction, organic farming, Mazovian voivodship, sustainable development.

\section{Introduction}

Intensive exploitation of environmental natural resources results in irreversible changes occurring in the plants' and animals' life. Nowadays the public awareness of the danger caused by unlimited use of natural resources is high, the consequence of which is so-called "sustainable development policy". This term became so important that it has been commonly used in publications concerning the environmental protection and building construction (e.g. Krause, 2004; Górecka, 2004; Czarnecki et al., 2012; Czarnecki \& Kaproń, 2012). Its precursor is the term "eco-development" (Stawicka-Wałkowska, 1998), coined in 1970's. A result of the environmental conference which took place in Rio de Janeiro, 1992, was the introduction of the term "sustainable development".

Hence, a problem exists, how to build, how to harmonize with the nature, how to provide energy and, finally, how to neutralize wastes so as the rich natural resources understood in general terms - serve us as long as possible and, first of all, serve next generations. The problem is not new at all, because already in 1833 J.C. Loudon published the design of an English cottage as a prototype of ecological, self-sufficient and energy-saving house (Sumień \& Wegner-Sumień, 1990).

In an era of increasing deterioration of the environment, the problem comes back with the doubled power (Bujak, 1995; Górzyński \& Panek, 1998). Thus, settle- 
ment systems must be entirely ecological so as they not threaten nature systems. A building becomes an element of the ecosystem and the building construction should be ecological (Mikoś-Rytel, 2000; Jeż \& Jeż, 2007; Chudzik \& Studziński, 1999).

A response could be the "green building" (Wodley et al., 1998/1999, Wodley, Kimmins, 1998/1999), in German “ökologisches Bauen” (Krusche, 1989). Ecological settlements and buildings protect the energy from non-renewable sources, take and preserve the energy from renewable natural sources, apply ecological methods of waste management and - in the final effect - constitute an active and very efficient link in the chain of the protection of the environment and its resources, thus it is the sustainable building construction (Niesłochowski, 1998; Aniuk et al., 1996) which is aimed i.a. on increase of durability and efficiency, material recycling, waste limitation, optimization of health conditions, possible preservation of the natural environment and maintenance of agricultural areas (Niesłochowski, 1998).

The alternative was being sought in the conventional agriculture as well - already in the beginning of the 20th century ("biologisch-dynamische Wirtschaftsweise", „organisch-biologischer Landbau”, „organic agriculture”, „l'agriculture biologique”; cf. Sołtysiak, 1993c). It resulted from philosophical or rather ideological premises. Nowadays, the organic farming is one of the development trends in agriculture. The document "Report on organic farming in Poland in 2015-2016" (Inspekcja Jakości Handlowej, 2017) states that according to the Eurostat's data Poland occupied 6th place in the European Union by account of the number of organic agricultural producers $(22,277$ subjects) and the 5th place by account of area of organic agricultural land (580,731 ha).

The organic agriculture problem was matter of interest of many researchers. It was being examined both in the international, national and regional perspective. Possibilities of its development were analyzed usually on the economic, social and agricultural level. The final scientific interpretation of the term "organic farming" has been yet not closed, it is variously formulated by various authors (Runowski, 1996; Sołtysiak, 1993a, b; Górny, 1992; Bechmann, 1993) and organizations (IFOAM, EKOLAND). "The organic farming is not a step backward in the civilization development but it is the most modern form of agriculture, based on the knowledge of nature laws" (Kośmicki, 1993). The organic farming is a production favoring the natural environment.

The term "organic farming" is used in Poland simultaneously (and even less frequently) with "ecological farming". These two terms and the third one, "biological farming", are recognized in the EU legislation (Council Regulation № 2092/91 of 24 June 1991) as synonyms; "organic farming" and "biological farming" are considerably older and come from historical names of methods of the agricultural production which were developed independently in various countries but contributed to derive the rules of the ecological farming from them.

It seems more natural that the problems of ecological construction should be of significant importance in the places where the ecology is the priority, i.e. in organic farms. They are the places which, through the application of ecology-friendly solutions, are identified much more intensively with their role as producers of organic food.

\section{Ecological building materials}

The production technology of building materials allows to apply more and more economical and ecological materials as well as entire construction systems being used to erect building objects consuming significantly lower quantities of energy on the stage of construction and exploitation (Górzyński, 2004; Kania et al., 1997). Ecological material and constructive solutions should be realized possibly in all types of building investments. The construction systems recognized as ecological must comply with many requirements. The precondition, but not sufficient condition, is low energy consumption for building exploitation. An important requirement is that the low energy consumption concerns the entire lifetime of the building - from the acquisition of primary raw materials, through production of building materials, construction process, building exploitation, its maintenance (durability requirements), modernization and demolition as well as re-use of the materials resulting from demolition. The processes should fulfill healthiness requirements in each stage; it concerns the stages from the acquisition of primary raw materials to the recycling of the materials resulting from demolition (Mikoś, 2000).

The following products are count by Mikoś (2000) among the ecological construction systems: the products made of silicate (Sawicki, 2009), the porous ceramics (Janiak, 1999a, 1999b), cellular concrete, plaster (Osiec$\mathrm{ka}, 2002)$. The unprocessed clay combined with straw is propagated as well (Pawlikowski, 1955; Racięcki, 1950; Stachowicz et al., 1993; Kamieniarz, 2009; Żurakowska, 2006; Kupiec-Hyła, 2008, 2009; Mankowski et al., 2014).

Another method is proposed by Kelm (1996). It consists in construction of houses made of clay blocks formed in special presses. Soil, pressed in the form of blocks, is an excellent building material (Kelm \& Długosz-Nowicka, 2011; Kelm et al., 2010).

Wood and wood-based materials (Stachowicz et al., 1993) or materials using hemp and its derivatives (Brzyski, 2016; Fic \& Brzyski, 2015) are also recognized as ecological building materials. 
It can be stated that the current building materials recognized as ecological have many environment- and human-friendly features but they are not free from disadvantages - in relation either to the materials themselves or to the process of their production or acquisition (np. Noszczyk et al., 2016; Backiel-Brzozowska, 2014; Kamieniarz, 2014).

Energy-saving building is often identified with ecological building what is not true, because ecological house means that it must be built of materials which are harmless for its residents, had been produced from components which are at least neutral for surroundings and the production process did not contributed to the degradation of the natural environment (Mikoś, 2000).

\section{Aim, scope and methodology of investigations}

The objective of the work was:

- to examine mutual connections between the ecological way of running a farm (certified organic farm) and building substance existing there (dwelling houses in that same farms),

- to check whether the material and constructive structure of the house is a result of conscious (ecological) action or rather it comes from previous years.

The thematic scope encompasses: an introduction in building materials or rather systems recognized as ecological, own surveys in selected organic farms concerning dwelling houses, quests for solutions. The methodology consisted in: analysis of the literature concerning ecological construction and organic farming; on-site visit and conversation with farm owners; analysis of the statistical data concerning organic farms in the Ostrołęka and Maków counties on background of the Mazovian voivodship.

\section{Results}

\subsection{Direct research}

The direct research was carried out on so-called small research sample in the north-east part of Mazovia. Two farms were selected from each of the districts: Łyse, Kadzidło and Różan, four from the district Młynarze. The Maków and Ostrołęka counties where the examined farms are situated are the most dynamically developing ones in terms of the number of organic farms in Mazovia. The total share of the organic farms in these counties in relation to the number of certified organic farms in the Mazovian voivodship was $11.2 \%$ (2016) and in relation to the whole Poland $1.2 \%(2015)$. This area had been chosen for research also for other reasons: one of the authors knows it well, the authors were curious how the organic farms in the vicinity of Ostrołęka develop and - the basic reason - to answer the question: did the change in the way of running a farm (into the ecological one) result in changes in the way of construction, modernization, renovation and exploitation of the dwelling buildings? It must be remembered that this area is poorly developed in terms of tourism and rather unknown. One of its chief assets is the closeness to the trunk road leading to Masurian Lakes. Only two from the examined farms take advantage of this fact and runs the agro-tourist activity - the ecological production can help to attract tourists, what was proposed by Dąbkowski (2003). Figures $1-10$ present the dwelling houses subjected to the research.

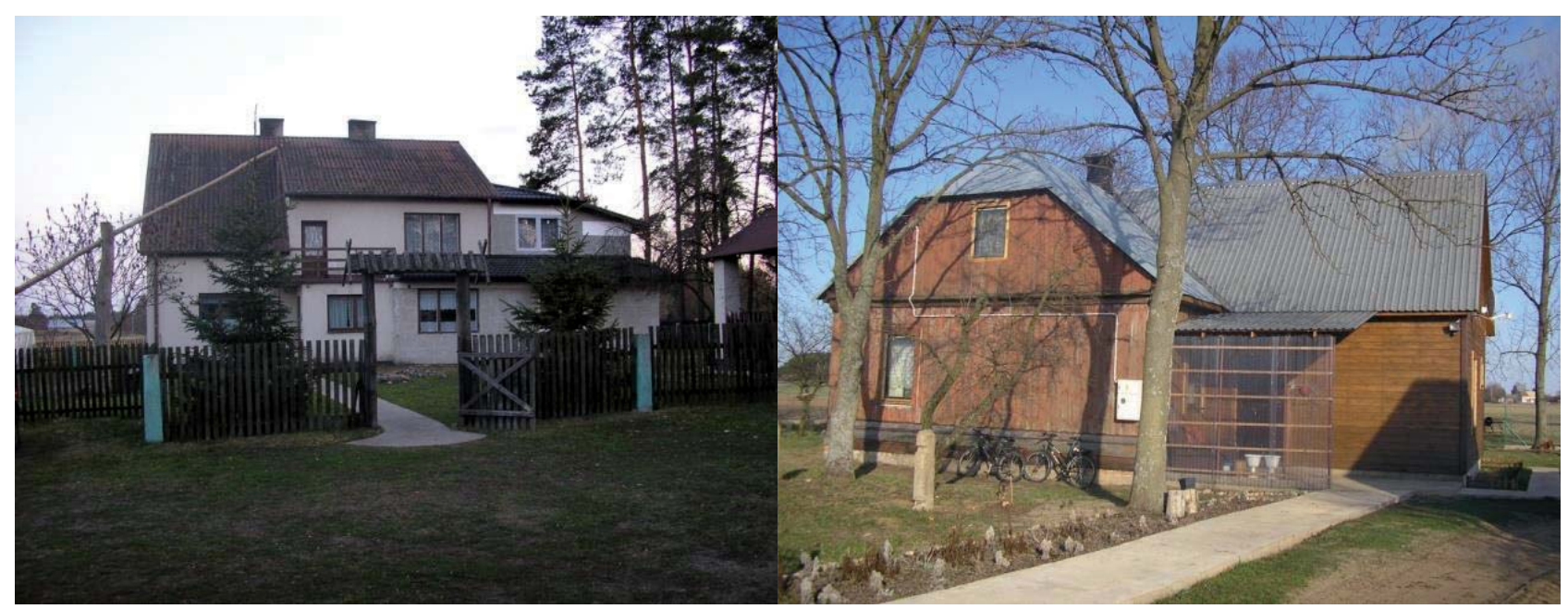

Figure 1. Building on farm 1 (photo by B. Pędzich)

Figure 2. Building on farm 2 (photo by B. Pędzich) 


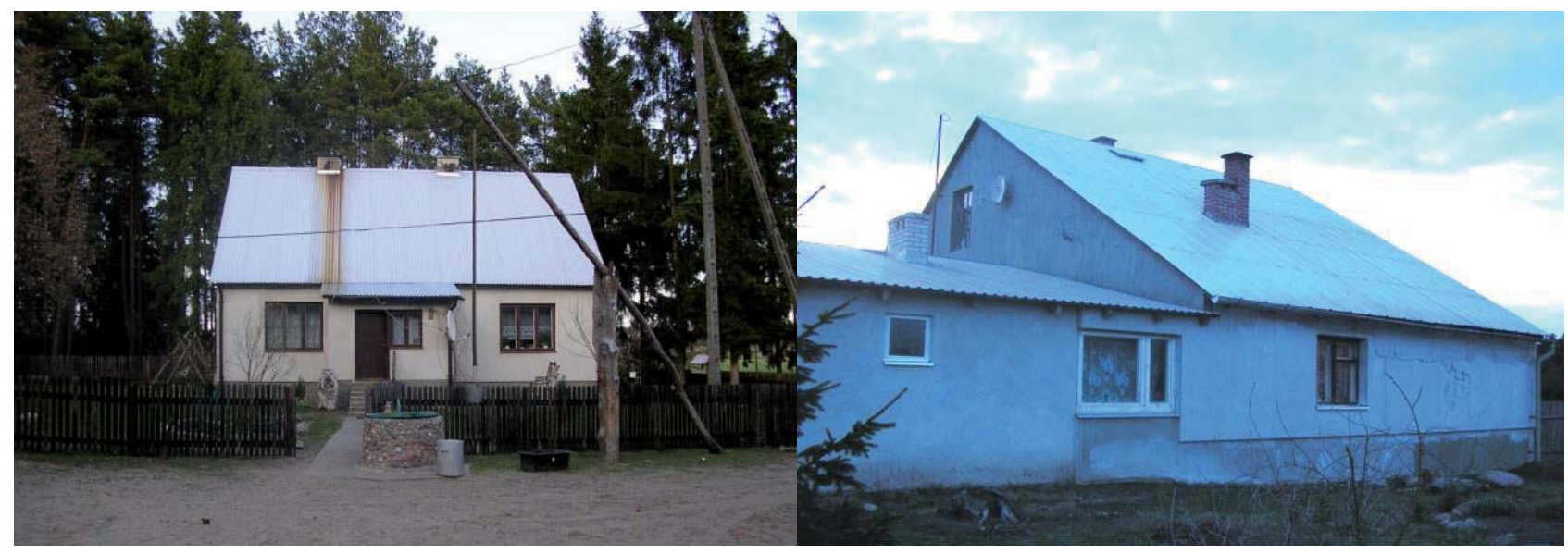

Figure 3. Building on farm 3 (photo by B. Pędzich)

Figure 4. Building on farm 4 (photo by B. Pędzich)

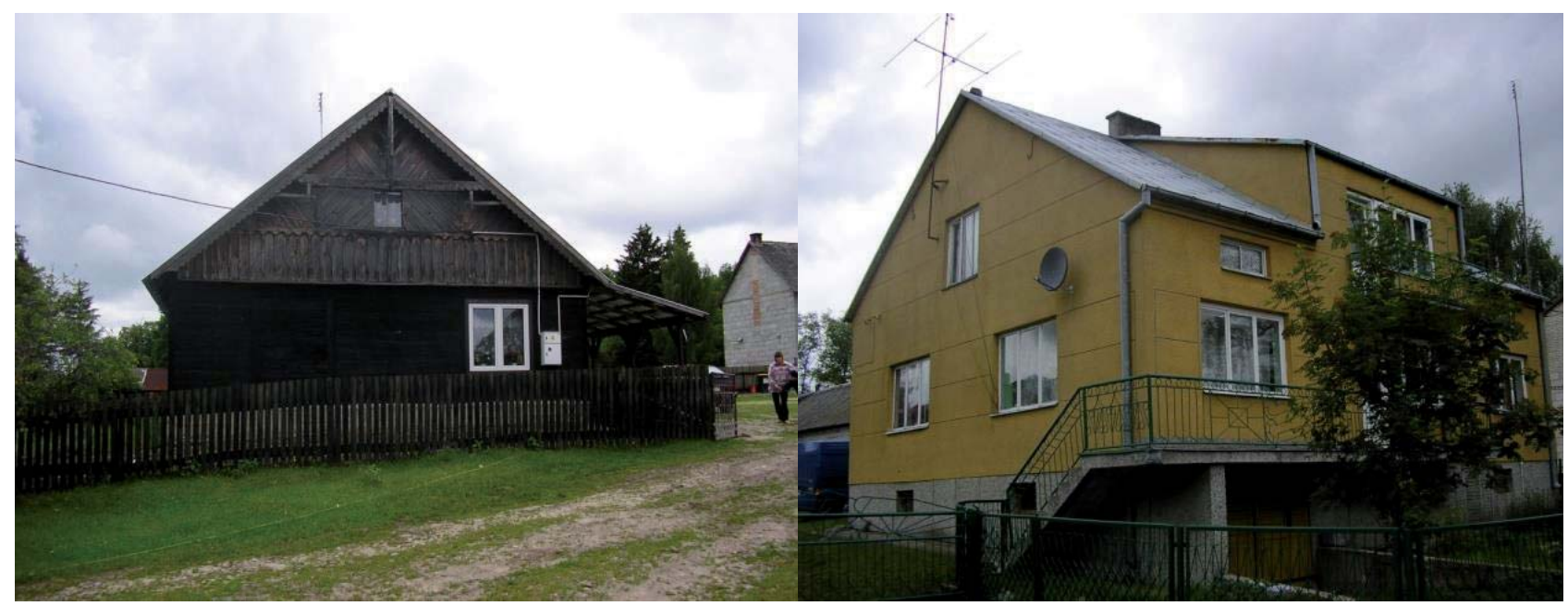

Figure 5. Building on farm 5 (photo by B. Pędzich)

Figure 6. Building on farm 6 (photo by B. Pędzich)

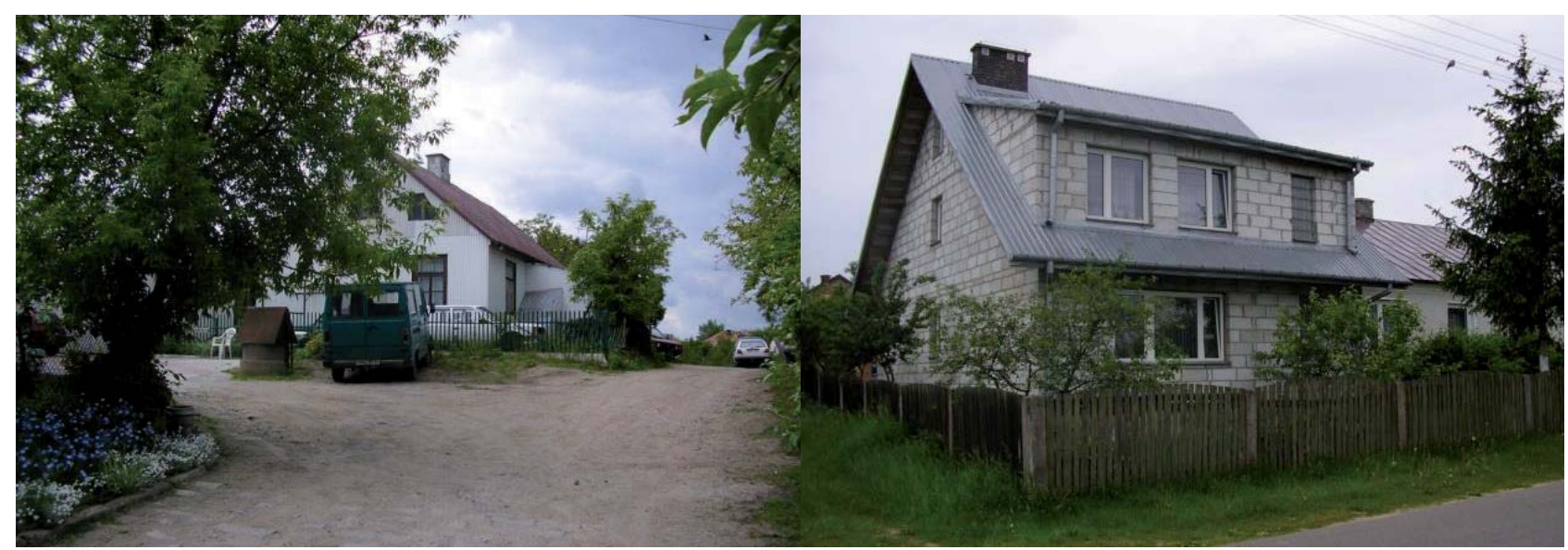

Figure 7. Building on farm 7 (photo by B. Pędzich)

Figure 8 . Building on farm 8 (photo by B. Pędzich) 


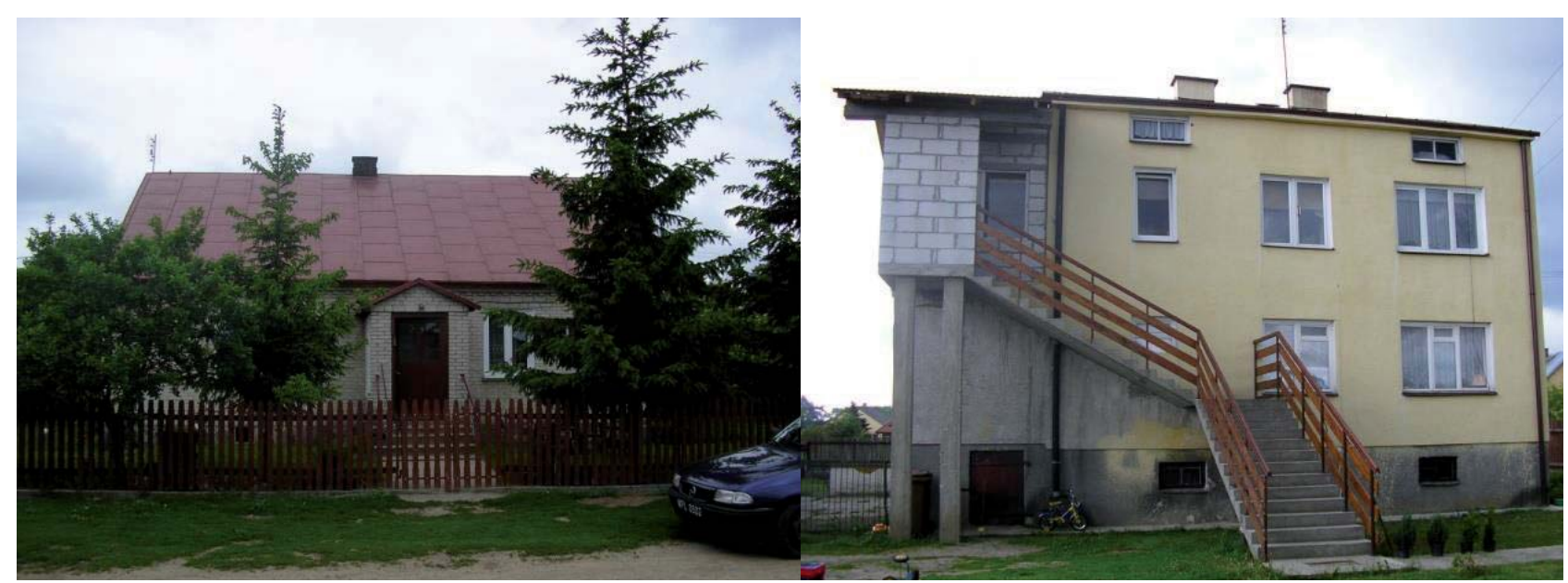

Figure 9. Building on farm 9 (photo by B. Pędzich)

\subsection{Analysis of the material obtained in direct research}

The majority of these houses is relatively old (one over 100-year old, four 40-year old, three were built in 1980's Fig. 11). Five buildings were subjected to renovations or modernizations (expansion, exchange of constructive elements, thermal modernization).

Taking the construction year into consideration and that in fact the older buildings were not subjected to renovation, the technical state can be evaluated (basing on on-site visits) as good (two buildings), medium (three buildings), satisfactory (four buildings), bad (one building). Seven build-
Figure 10. Building on farm 10 (photo by B. Pędzich)

ings were built using the traditional masonry technology, three - the wooden technology. The houses mainly constitute an uncomplicated solid, partly or entirely with a basement and a usable attic. All of the examined buildings are set on a continuous footing, $60 \%$ of the footing is made of ferroconcrete, $40 \%$ - of concrete. Foundation walls in one of the buildings are built of crushed stone, whereas in the remaining nine - of ferroconcrete, full bricks and full concrete blocks, with the same share of these materials between the buildings. Over the half of the examined buildings is not insulated. The most masonry buildings are constructed with double-layered wall (Fig. 12).

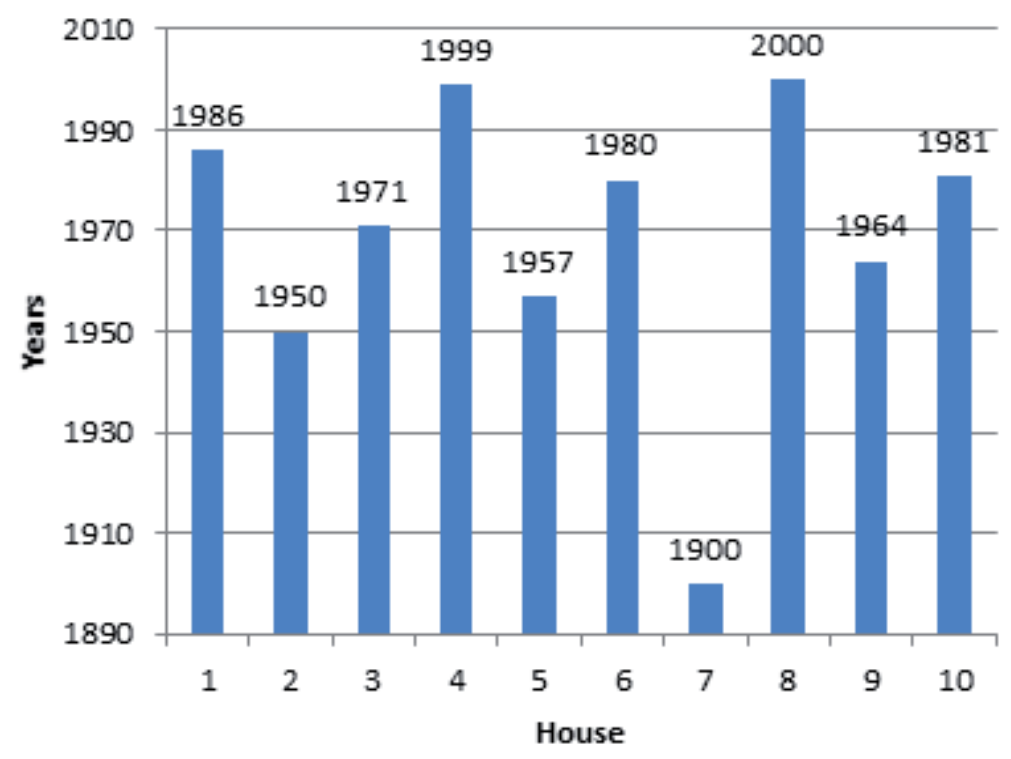

- Year of construction

Figure 11. Year of construction of houses 
The material solutions of external walls in the discussed buildings are diverse and presented in Fig. 13 (it should be added that the external and internal walls in part of the buildings were built of various materials).

The material solutions of internal walls are based mainly on various types of ceramic brick and wooden constructions (Figs 14 and 15).

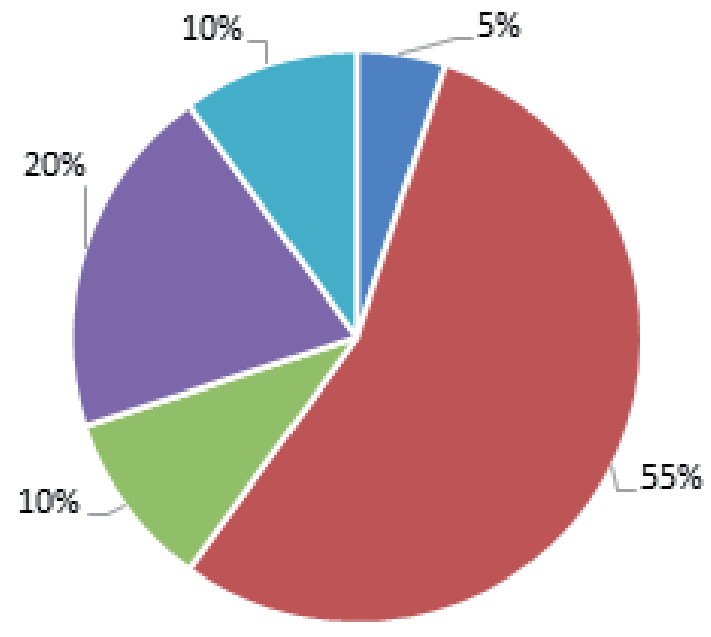

Figure 12. Construction of external walls in the examined buildings

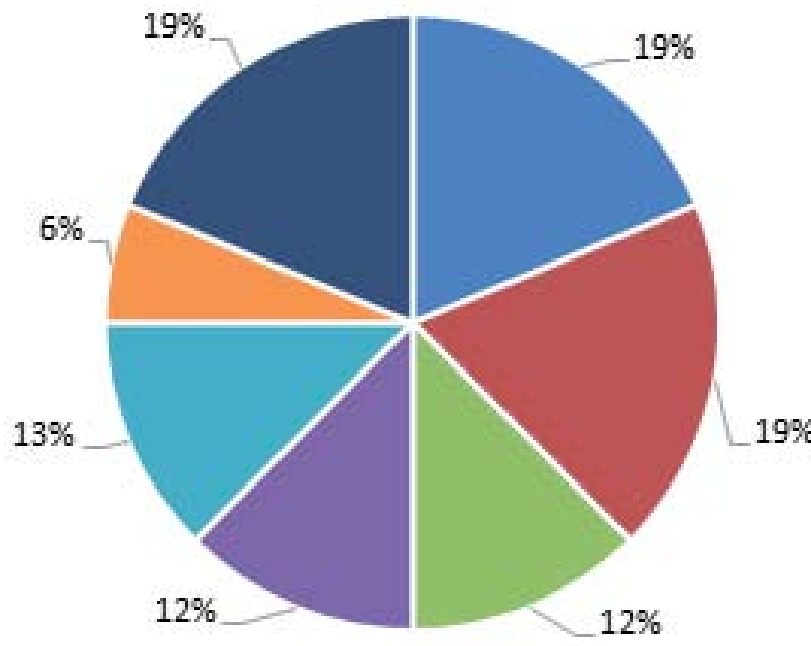

- lime-sand brick

- cellular concrete blocks

I. aerated concr ete with $a$ h

- Alfa hollow brick

- ceramic br ick

- Max hollow brick

- wood

Figure 13. Material solutions of external walls in the examined buildings 


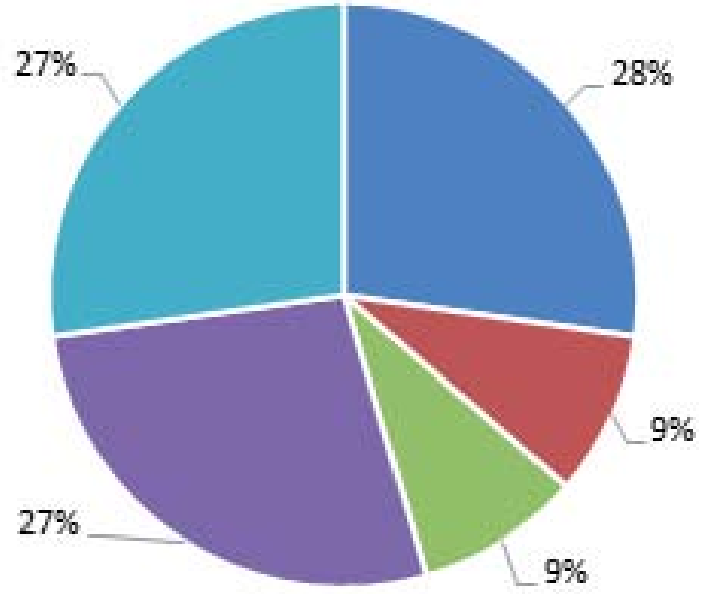

Figure 14. Material solutions of internal structural walls the examined buildings

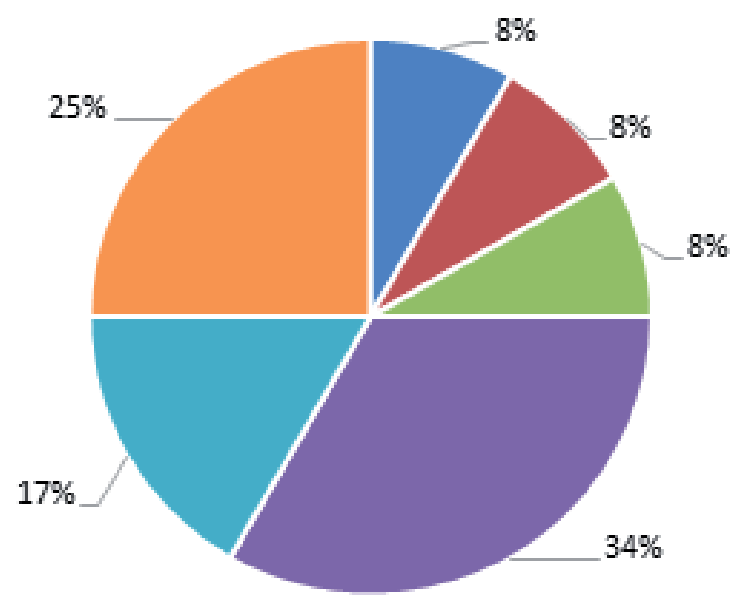

Figure 15. Material solutions of internal walls in the examined buildings

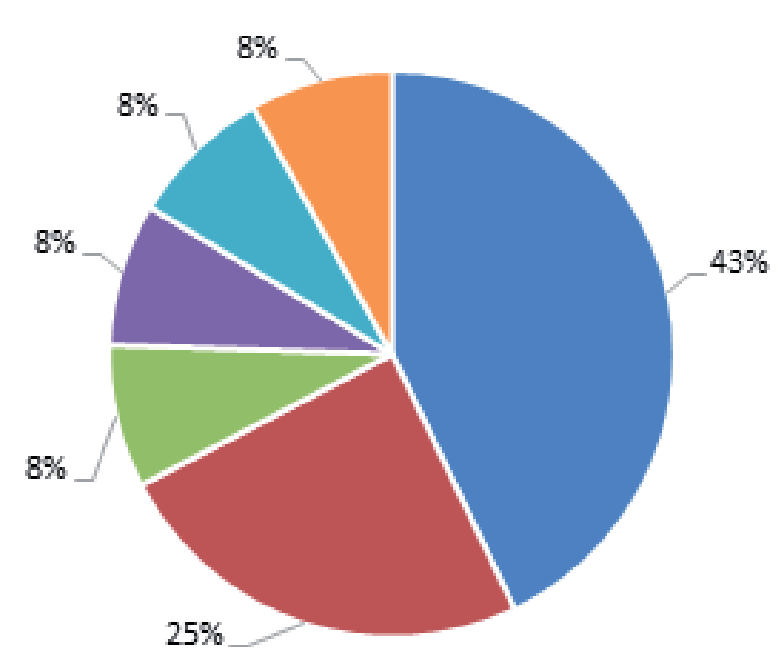

Figure 16. Construction of floors in the examined buildings

\section{- cellular concrete blocks}

- aerated concrete

= Alfa hollow brick

full brick

- wooden elements n aerated concr ete

- Alfa hollow brick

- cored ceramic brick

- porous ceramic brick

w wooden elements

- wooden beam floor

- Klein floor

w slab ferroconcretefloor

n Teriva floor

= brick floor on T27 beams

- WPS slab floor on steel beams 
All buildings have wooden rafter framing, the roofs are covered with metal plate on the nine buildings in various forms (sheets, sheet roofing tiles, trapezoidal sheets). There are asbestos-cement plates in one of the buildings on one part of the roof. The form of thermal insulation is different (Styrofoam, mineral wool) or does not exist at all.

\section{Discussion and conclusions}

The direct research, carried out in selected organic farms of the Mazovian voivodship, show that the material and constructive solutions of houses come from before the conversion of the farm in ecological one. All buildings had been built before this moment. Rare, individual cases referring to the concept of ecological building construction - through the material applied - are the result of accessibility of one and not a different material in the period of erection of the object. They arise not from an intentional choice of pro-ecological solutions but from coincidence.

Dąbkowski (2002b) developed a method of evaluation of a farm from an ecological point of view. One of the evaluation criteria were the building materials used to erect buildings on a farm plot. Basing on the literature, three groups of materials were distinguished: ecological, mixed (buildings made of ecological and non-ecological materials) and non-ecological. It should be considered whether the fourth group is to be distinguished - harmful materials (asbestos, slag etc.). Each building can be given an appropriate number of credits. According to this method, almost all examined buildings should be counted into the category "mixed"; one building should be classified in the category "harmful" due to the asbestos-cement roof cover.

In spite of the passing time, the conclusions contained in the work by Dąbkowski (2002a), pronouncing that "the buildings in Polish organic farms - dwelling houses, livestock and farm buildings - are built mainly of non-ecological, highly processed and energy consuming materials", prove correct. In the buildings described in this paper, differently than by Dąbkowski (2002a), the problem of roofing containing asbestos almost does not occur (it was found only on one building, on a part of the roof).

It is required that a building and its heating, ventilation and air-conditioning installations be designed and completed in such a way that permits the quantity of heat energy needed to use building according its purpose to be maintained on a rationally low level - what cannot be fulfilled in the case of the examined buildings due to the type of construction of the external walls, as noted by Dąbkowski and Matuszewicz (2010). From the point of view of the new heat requirements arising out of the Regulation of Minister of Transport, Construction and Marine
Economy of 5 July 2013, changing the decree on technical conditions to be met by buildings and their location (Rozporządzenie, 2013), one should strive to carry out any renovations and modernizations of buildings of all kind, not only dwelling ones, localized in organic farms, with application of the materials currently considered as ecological and energy-saving.

It is also important to use the heritage of generations (Ciołek, 1984; Ruszczyk, 2007; Iwanicki, 1917; Bułhak et al., (eds), 2011) manifesting i.a. in the traditional folk technique which - "using of a number of possibilities, faced up to many complex and often variable functions of a dwelling house" (Tłoczek, 1985).

Tłoczek (1985) confirmed the dependence of the form of traditional Polish folk house on natural forces - the allied and antagonistic ones. Among the environmental factors which played the strongest role in the past house architecture shaping, he names two: climate and landform features. He also states that "air temperature, insolation, precipitations and winds were the active and variable forces whereas landform features, flora, surface water and groundwater, accessible building materials constituted a set of relatively stable conditions". Due to that, he formulates a conclusion: "the adaptation of human to the natural environment manifests first of all in the shape of huts, in their construction, in insulation parameters of walls and floors, in house layout, in localization and size of door and window openings, in roof slope angle, in eaves protrusion - in a word, in the basic house elements".

It seemed that the region rich in folk traditions concerning architectural details and decorative elements (Kurpie Zielone, borderland of Kurpie Białe) should have abounded in constructions made of local materials (wood) - but because of trends in building construction of the latest 60 - 70 years the folk architecture has been replaced by a unified house which lost precious values being in accordance with the nature (and being an immanent feature of the regional architecture) and, hence, has very few in common with the ecological construction.

\section{References}

Aniuk D., Boonstra Ch. \& Mak J., 1996, Handbook of Sustainable Building, An Environmental Preference Method for Selection of Materials for Use in Construction and Refurbishment. James \& James, London.

Backiel-Brzozowska B., 2014, Budownictwo z gliny i słomy - wstępna ocena wybranych aspektów trwałości [Clay- and straw-based building construction - preliminary evaluation of selected aspects of durability]. Inżynieria Ekologiczna 40: 208-216. 
Bechmann A., 1993, Rolnictwo ekologiczne - owoc XX wieku [Organic agriculture - fruit of the $20^{\text {st }}$ century], [in:] U. Sołtysiak (ed.), Rolnictwo ekologiczne od teorii do praktyki [Organic farming from theory to practice]. Stowarzyszenie Ekoland, Stiftung Leben \& Umwelt, Warszawa: 13-22.

Bujak T., 1995, Ekologiczne i ekonomiczne aspekty budownictwa [Ecological and economical aspects of agriculture], VII Ogólnopolska Interdyscyplinarna Konferencja Naukowo-Techniczna Ekologia a budownictwo [7th Polish Interdisciplinary Scientific and Technical Conference Ecology vs. Building Construction]. Urząd Wojewódzki w Bielsku-Białej, Instytut Techniki Budowlanej, Polski Związek Inżynierów i Techników Budownictwa Oddział w Bielsku-Białej, Bielsko-Biała: 209-222.

Brzyski P., 2016, Budownictwo z wykorzystaniem kompozytu wapienno-konopnego - charakterystyka materiału [Constructions with application of lime-hemp composite]. Przegląd Budowlany 87/1: 29-33.

Bułhak D., Połąski K. \& Potok A. (ed.), 2011, Rzecz o dziedzictwie na wsi. Rady, przykłady, informacje [A word on heritage on country. Advices, examples, information]. Fundacja Wspomagania Wsi, Warszawa.

Chudzik B. \& Studzinski J., 1999, Budownictwo ekologiczne i jego uwarunkowania [Ecological construction and its determinants]. Zeszyty Naukowe Akademii Rolniczej we Wrocławiu. Konferencje 22: 273-287.

Ciołek G., 1984, Regionalizm w budownictwie wiejskim w Polsce [Regionalism in rural architecture in Poland]. Wydawnictwo Politechniki Krakowskiej, Kraków.

Council Regulation (EEC) No. 2092/91 of 24 June 1991 on organic production of agricultural products and indications reffering thereto on agricultural products and foodstuffs. European Commission OJL 198, 1991-0722, Brussels: 1-15.

Czarnecki L. \& Kaproń M., 2012, Budownictwo przyszłości $=$ zrównoważone budownictwo [Construction of the future = sustainable construction]. Materiały Budowlane 1: 72-73.

Czarnecki L., Kaproń M., Piasecki M. \& Wall S., 2012, Budownictwo zrównoważone budownictwem przyszłości [Sustainable construction - construction of the future]. Inżynieria i Budownictwo 68/1: 18-21.

Dąbkowski N., 2002a, Nieekologiczne zabudowania w ekologicznych gospodarstwach [Non-ecological buildings in ecological farms]. Problemy Rozwoju Budownictwa, 1, Instytut Gospodarki Mieszkaniowej, Warszawa: 37-41.

Dąbkowski N., 2002b, Metoda i kryterium oceny zagrody pod względem ekologicznym [Method and criterium of evaluation of a farmstead from ecological point of view]. Przegląd Naukowy Inżynieria i Kształtowanie Środowiska 2(25): 182-186.
Dąbkowski N., 2003, Gospodarstwa ekologiczno-turystyczne elementem rozwoju polskiej wsi [Ecotourist farms as an element of the development of the Polish country], [in:] D. Korolczuk (ed.), X Międzynarodowa Konferencja Kierunki planowania przestrzennego i architektury współczesnej wsi: współczesne przekształcenia przestrzenne obszarów wiejskich - stan istniejący oraz uwarunkowania i możliwości rozwoju [10th International Conference Trends of Spatial Planning and Architecture of Contemporary Country: Existing State and Deteminants and Possibilities of Development]. Wydział Architektury Politechniki Białostockiej, Komisja Urbanistyki i Architektury O/ PAN w Krakowie, Białystok: 115-119.

Dąbkowski N. \& Matuszewicz K., 2010, Analiza cieplna zewnętrznych przegród pionowych w budynkach mieszkalnych wybranych gospodarstw ekologicznych w województwie podkarpackim [Heat analysis of external vertical baffles in dwelling houses of selected ecological farms in Subcarpathian voivodship]. Acta Scientiarum Polonorum Architectura 9(1): 41-49.

Fic S. \& Brzyski P., 2015, O technologii wykonywania ścian z wykorzystaniem kompozytu zawierającego paździerze konopne [On technology of application of walls using a composite containing hemp shove harl]. Inżynieria i Budownictwo 71/7: 356-358.

Górecka M., 2004, Architektura energooszczędnego domu mieszkalnego polskiej wsi w aspekcie zrównoważonego rozwoju [Architecture of energy-saving dwelling house of the Polish country]. Wydawnictwo Politechniki Warszawskiej, Warszawa.

Górny M., 1992, Eko-filozofia rolnictwa [Ecophilosophy of agriculture]. Centrum Edukacji Ekologicznej Wsi, Krosno.

Górzyński J., 2004, Kierunki proekologicznej racjonalizacji wyrobów budowlanych [Trends in ecologicalfriendly rationalization of building products], XVI Ogólnopolska Interdyscyplinarna Konferencja Naukowo-Techniczna Ekologia a Budownictwo [16th Polish Interdisciplinary Scientific and Technical Conference Ecology vs. Building Construction]. Zarząd Główny Polskiego Związku Inżynierów i Techników Budownictwa Komitet Ekologii, Instytut Techniki Budowlanej, Politechnika Krakowska, Polski Związek Inżynierów i Techników Budownictwa Oddział w Bielsku-Białej, Bielsko-Biała: 95-104.

Górzyński J. \& Panek A., 1998, Wymagania stawiane budownictwu przyjaznemu środowisku na przykładzie Green Building Challenge [Requirements set before environment-friendly construction in the case of Green Building Challenge], X Ogólnopolska Interdyscyplinarna Konferencja Naukowo-Techniczna Ekologia a budownictwo [10th Polish Interdisciplinary Scientific and Technical Conference Ecology vs. Building 
Construction]. Urząd Wojewódzki w Bielsku-Białej, Instytut Techniki Budowlanej, Politechnika Krakowska, Polski Związek Inżynierów i Techników Budownictwa Oddział w Bielsku-Białej, Bielsko-Biała: 101111.

Inspekcja Jakości Handlowej Artykułów Rolno-Spożywczych [Agricultural and Food Quality Inspection], 2017, Raport o stanie rolnictwa ekologicznego w Polsce w latach 2015-2016 [Report on organic farming in Poland in 2015-2016. (http://www.ijhar-s.gov.pl/ index.php/raporty-o-ekologii.html).

Iwanicki K., 1917, Budownictwo wiejskie. Poradnik przy wznoszeniu zabudowań na wsi [Rural architecture. Guide on erection of buildings in rural areas]. Kijów, Warszawa, reprint 2007, Wydawnictwo Górnoleśne, Milanówek.

Janiak M., 1999a, Budownictwo ekologiczne z cegły ceramicznej, cz. 1 [Ceramic brick-based ecological construction, part 1]. Ceramika Budowlana i Silikaty 41/1: 22-26.

Janiak M., 1999b, Budownictwo ekologiczne z cegły ceramicznej, cz. 2 [Ceramic brick-based ecological construction, part 1]. Ceramika Budowlana i Silikaty 41/2: 11-16.

Jeż J. \& Jeż T., 2007, Budownictwo jako element ekosystemu [Building construction as an element of the ecosystem], XVIII Ogólnopolska Interdyscyplinarna Konferencja Naukowo-Techniczna Ekologia a budownictwo [18th Polish Interdisciplinary Scientific and Technical Conference Ecology vs. Building Construction]. Zarząd Główny Polskiego Związku Inżynierów i Techników Budownictwa Komitet Ekologii, Instytut Techniki Budowlanej, Politechnika Krakowska, Politechnika Śląska, Polski Związek Inżynierów i Techników Budownictwa Oddział w Bielsku-Białej, Śląska Okręgowa Izba Inżynierów Budownictwa w Katowicach, Bielsko - Biała: 81-90.

Kamieniarz M., 2009, Proekologiczne budownictwo gliniane [Ecological-friendly clay-based construction]. Warstwy, Dachy i Ściany 3: 46-47.

Kamieniarz M., 2014, Budownictwo z gliny w aspekcie energooszczędności i ochrony środowiska [Clay-based construction in aspect of energy savings and environmental protection]. Materiały Budowlane 11: 51-53.

Kania S. Musiał W. Suwalski J. \& Zwierzchowska Z., 1997, Nieekologiczne ekologiczne rozwiązania konstrukcyjne w budownictwie [Non-ecological ecological constructive solutions in building construction], IX Ogólnopolska Interdyscyplinarna Konferencja Naukowo-Techniczna Ekologia a Budownictwo [9th Polish Interdisciplinary Scientific and Technical Conference Ecology vs. Building Construction], Urząd Wojewódzki w Bielsku-Białej, Instytut Techniki Budowlanej, Politechnika Krakowska, Polski Związek
Inżynierów i Techników Budownictwa Oddział w Bielsku-Białej, Bielsko-Biała: 99-105.

Kelm T., 1996, Architektura ziemi. Tradycja i współczesność [Architecture of soil. Tradition and contemporaneity]. Wydawnictwo Murator, Warszawa.

Kelm T. \& Długosz-Nowicka D., 2011, Budownictwo z surowej ziemi. Idea i realizacja [Raw soil based building construction. Idea and realization]. Oficyna Wydawnicza Politechniki Warszawskiej, Warszawa.

Kelm T. Górski J. Kołłątaj M. \& Gawrońska P., 2010, Budownictwo z surowej ziemi - ekologia i nowoczesny standard: prezentacja realizacji budynku doświadczalnego, zlokalizowanego w Parku Ekologicznym w Pasłęku [Raw soil based building construction - ecology and modern standard: presentation of the realization of an experimental building in Ecological Park in Pasłęk]. Aparatura Badawcza i Dydaktyczna 15/2: 31-38.

Kośmicki E., 1993, Tendencje rozwojowe rolnictwa na świecie i w Polsce [Trends in development of agriculture in Poland and in the world], [in:] U. Sołtysiak (ed.), Rolnictwo ekologiczne od teorii do praktyki [Organic farming from theory to practice]. Stowarzyszenie Ekoland, Stiftung Leben \& Umwelt, Warszawa: 39-44.

Kupiec-Hyła D., 2008, Bliżej natury - zrównoważone budownictwo mieszkaniowe $\mathrm{z}$ gliny niepalonej [Closer to nature - sustainable adobe housing construction]. Zeszyty Naukowe Politechniki Rzeszowskiej, Budownictwo i Inżynieria Środowiska 47(252): 225-230.

Kupiec-Hyła D., 2009, Budownictwo z gliny szansą na ekorozwój [Clay-based construction - a chance for sustainable development]. Warstwy, Dachy i Ściany 2: 76-77.

Krause H., 2004, Uwarunkowania zrównoważonego rozwoju w budownictwie [Determinants of the sustainable development in building construction], XVI Ogólnopolska Interdyscyplinarna Konferencja Naukowo-Techniczna Ekologia a budownictwo [16th Polish Interdisciplinary Scientific and Technical Conference Ecology vs. Building Construction]. Zarząd Główny Polskiego Związku Inżynierów i Techników Budownictwa Komitet Ekologii, Instytut Techniki Budowlanej, Politechnika Krakowska, Polski Związek Inżynierów i Techników Budownictwa Oddział w Bielsku-Białej, Bielsko-Biała: 47-52.

Krusche H., 1989, Ökologisches Bauen, Bauverlag, München.

Mankowski P., Krzosek S. \& Mikolajko M., 2014, Ecological, clay-based building engineering. Annals of Warsaw University of Life Sciences - SGGW. Forestry and Wood Technology 85: 149-155.

Mikoś J., 2002, Budownictwo ekologiczne [Ecological building construction]. Wydawnictwo Politechniki Śląskiej, Gliwice. 
Mikoś-Rytel W., 2000, O architektonicznym kształtowaniu ekologicznych budynków mieszkalnych [On the architectural shape of ecological residential buildings], XII Ogólnopolska Interdyscyplinarna Konferencja Naukowo - Techniczna Ekologia a budownictwo [12th Polish Interdisciplinary Scientific and Technical Conference Ecology vs. Building Construction]. Śląski Urząd Wojewódzki w Katowicach Wydział Zamiejscowy w Bielsku-Białej, Instytut Techniki Budowlanej, Politechnika Krakowska, Polski Związek Inżynierów i Techników Budownictwa Oddział w Bielsku-Białej, Bielsko-Biała: 145-152.

Niesłochowski A., 1998, Budownictwo zrównoważone, metody oceny, przykładowe rozwiązania w krajach U.E. [Sustainable building construction - methods of evaluation, example solutions in EU countries], X Ogólnopolska Interdyscyplinarna Konferencja Naukowo - Techniczna Ekologia a budownictwo [10th Polish Interdisciplinary Scientific and Technical Conference Ecology vs. Building Construction]. Urząd Wojewódzki w Bielsku-Białej, Instytut Techniki Budowlanej, Politechnika Krakowska, Polski Związek Inżynierów i Techników Budownictwa Oddział w Bielsku-Białej, Bielsko-Biała: 47-56.

Noszczyk P., Nowak L., Peszek A. \& Rumijowska A., 2016, Wybrane problemy budownictwa ze słomy [Selected problems of straw-based building construction]. Fizyka Budowli w Teorii i Praktyce 8/2: 29-34.

Osiecka E., 2002, Materiały gipsowe w budownictwie dawniej i obecnie [Plaster materials in building construction - in past and nowadays]. Cement Wapno Beton 7/69/5: 201-205.

Pawlikowski M., 1955, Nowoczesne budownictwo z gliny [Modern clay-based construction]. Państwowe Wydawnictwa Rolnicze i Leśne, Warszawa.

Racięcki Z., 1950, Budownictwo z gliny [Clay-based construction]. Państwowe Wydawnictwo Techniczne, Warszawa.

Rozporządzenie Ministra Transportu, Budownictwa i Gospodarki Morskiej z dnia 5 lipca 2013 r. zmieniające rozporządzenie w sprawie warunków technicznych, jakim powinny odpowiadać budynki i ich usytuowanie. Dz. U. 2013, poz. 926. Kancelaria Prezesa Rady Ministrów [Regulation of the Minister of Transport, Construction and the Maritime Economy of 5 July 2013, amending regulation on on the technical conditions that should be met by buildings and their location. Journal of Laws 2013, item 926. Chancellary of the Prime Minister], Warszawa.

Runowski H., 1996, Ograniczenia i szanse rolnictwa ekologicznego [Limitations and chances of ecological farming]. Wydawnictwo SGGW, Warszawa.

Ruszczyk G., 2007, Drewno i architektura: dzieje budownictwa drewnianego w Polsce [Wood and architec- ture: history of the wooden construction in Poland]. Wydawnictwo „Arkady”, Warszawa.

Sawicki J., 2009, Silikaty w budownictwie [Silicates in building construction]. Izolacje 14/1: 82-87.

Sołtysiak U., 1993a, Eko-rolnictwo - szansa na polską specjalność [Eco-agriculture - Chance for a Polish specialization], [in:] U. Sołtysiak (ed.), Rolnictwo ekologiczne od teorii do praktyki [Organic farming from theory to practice]. Stowarzyszenie Ekoland, Stiftung Leben \& Umwelt, Warszawa: 111-117.

Sołtysiak U., 1993b, Z początków rolnictwa ekologicznego w Polsce [On the beginnings of the organic farming in Poland], [in:] U. Sołtysiak (ed.), Rolnictwo ekologiczne od teorii do praktyki [Organic farming from theory to practice]. Stowarzyszenie Ekoland, Stiftung Leben \& Umwelt, Warszawa: 239-243.

Sołtysiak U., 1993c, Rolnictwo ekologiczne - historyczny przegląd metod [Organic farming - historical review of methods], [in:] U. Sołtysiak (ed.), Rolnictwo ekologiczne od teorii do praktyki [Organic farming from theory to practice]. Stowarzyszenie Ekoland, Stiftung Leben \& Umwelt, Warszawa: 23-38.

Stachowicz A., Gintowt J. \& Wojdyło-Wróbel J., 1993, Glina - niedoceniany materiał budowlany [Clay - underestimated building material], V Ogólnopolska Konferencja Naukowo-Techniczna Ekologia a Budownictwo [5th Polish Scientific and Technical Conference Ecology vs. Building Construction]. Urząd Wojewódzki w Bielsku-Białej, Polski Związek Inżynierów i Techników Budownictwa Oddział w Bielsku-Białej, Bielsko-Biała: 145-150.

Stachowicz A., Kram D.\& Rawski A., 1993,. Drewno materiał ekologiczny z surowca odnawialnego i jego wykorzystanie w budownictwie [Wood - an ecological material based on a renewable resource and its application in construction], V Ogólnopolska Konferencja Naukowo - Techniczna Ekologia a Budownictwo [5th Polish Scientific and Technical Conference Ecology vs. Building Construction]. Urząd Wojewódzki w Bielsku-Białej, Polski Związek Inżynierów i Techników Budownictwa Oddział w Bielsku-Białej, Bielsko-Biała: 151-156.

Stawicka-Wałkowska M., 1998, Dostosowanie budownictwa i przemysłu materiałów budowlanych do założeń zrównoważonego rozwoju [Adaptation of building construction and building material industry to the assumptions of the sustainable development], X Ogólnopolska Interdyscyplinarna Konferencja Naukowo-Techniczna Ekologia a budownictwo [10th Polish Interdisciplinary Scientific and Technical Conference Ecology vs. Building Construction]. Urząd Wojewódzki w Bielsku-Białej, Instytut Techniki Budowlanej, Politechnika Krakowska, Polski Związek Inżynierów 
i Techników Budownictwa Oddział w Bielsku-Białej, Bielsko-Biała: 41-46.

Sumień T. \& Wegner-Sumień A., 1990, Ekologiczne miasta, osiedla i budynki [Ecological cities, settlements and buildings]. Instytut Gospodarki Przestrzennej i Komunalnej, Warszawa.

Tłoczek I.F., 1985, Dom mieszkalny na polskiej wsi [Dwelling house in the Polish country]. Państwowe Wydawnictwo Naukowe, Warszawa.
Wodley T., Kimmins S., Harrison P. \& Harison R., 1998/1999, Green Building Handbook, Vol. 1. E\&FN Spon, New York.

Wodley T. \& Kimmins S., 1998/1999, Green Building Handbook, Vol. 2. E\&FN Spon, New York.

Żurakowska M., 2006, Budownictwo z gliny surowej [Raw clay-based building construction]. Recykling 5: 28-29. 